\title{
FAKTOR-FAKTOR YANG MEMPENGARUHI DISIPLIN PEGAWAI TERHADAP PENINGKATAN KINERJA PADA KANTOR CAMAT DARUSSALAM KABUPATEN ACEH BESAR
}

\author{
Syamsul Akmal $^{(1)}$, Mahrizal ${ }^{(2)}$ \\ ${ }^{1,2}$ Fakultas Ekonomi Universitas Jabal Ghafur \\ ${ }^{(1)}$ syamsul_akmal24@yahoo.com, ${ }^{(2)}$ mahrizal4@gmail.com
}

\begin{abstract}
ABSTRAK
Penelitian ini dilakukan pada Kantor Camat Darussalam Kabupaten Aceh Besar dengan objek penelitiannya adalah kinerja pegawai sedangkan subjeknya adalah berupa faktor yang mempengaruhi Disiplin yaitu; faktor kehadiran, faktor ketaatan pada aturan kerja, faktor ketaatan pada standar kerja, faktor tingkat kewaspadaan yang tinggi, dan faktor bekerja etis, dengan mengambil sampel adalah seluruh pegawai yang 25 orang yang akan menjadi respoden dalam penelitian ini. Dari penelitian yang dilakukan dengan metode input data memakai kuesioner kepada responden dan data tersebut dianalisa dengan memakai skala likert, pengolahan data dipergunakan program SPSS versi21, maka dari hasil output hasilnya dimana pengujian regresi adalah faktor yang mempengaruhi disiplin pegawai secara partial adalah dengan uji $\mathrm{t}$ yaitu $\mathrm{t}_{\text {hitung }}>\mathrm{t}_{\text {tabel }}$, variabel Disiplin mempunyai $11.899<\mathrm{t}_{\text {tabel }} 2.064$ berpengaruh secara siqnifikan terhadap kinerja pegawai pada Kantor Camat Darussalam Kabupaten Aceh Besar. Pengujian tingkat hubungan (pengujian korelasi) dimana tingkat hubungan antara faktorfaktor disiplin dengan kinerja pegawai 0,933 atau sebesar 93.3\% pada tingkat koefisien korelasi (R) mempunyai hubungan yang sangat kuat sedangkan koefisien determinasi $\left(\mathrm{R}^{2}\right)$ adalah 0,871 atau $87.1 \%$ bahwa perubahan pada variabel terikat dapat dijelaskan oleh variabel yang diteliti dan hanya $12,9 \%$ yang dipengaruhi oleh variabel lain yang tidak diteliti dalam penelitian ini.
\end{abstract}

Kata kuncinya adalah: $\quad$ Faktor Kehadiran, Ketaatan pada aturan kerja, Ketaatan pada standar kerja, Tingkat kewaspadaan yang tinggi, Bekerja etis, dan Kinerja

\section{Latar Belakang Permasalahan.}

Perubahan lingkungan ekternal organisasi dan lembaga seperti perubahan kondisi ekonomi dan tuntutan pelayanan masyarakat yang lebih baik harus didukung oleh perubahan lingkungan internal seperti peningkatan sumber daya manusiayang dapat merespon serta menuntut organisasi untuk bersikap fleksibel dalam merespon dan memanfaatkan peluang yang ditimbulkan oleh perubahan lingkungan tersebut, sehingga organisasi dapat mempertahankan kelangsungan hidupnya walaupun berada dalam pesaingan yang sangat ketat.

Kemampuan dan keahlian dari sumber daya manusia(SDM) yang dimiliki organisasi merupakan asset yang tidak nampak (intangible asset) yang menjadi keunggulan kompetitif suatu organisasi dan dapat menciptakan nilai organisasi, hal ini disebabkan karena keberadaan manusia sangat dengan unsur lainnya dalam sebuah organisasi, karena sumber daya manusiamerupakan unsur penggerak jalannya organisasi, berapapun besarnya sumber daya lain dalam sebuah organisasi tanpa didukung oleh Sumber daya manusiayang handal, maka organisasi tersebut tidak dapat berkembang dan tidak dapat menciptakan nilai tambah bagi sumber daya lainnya.

Sebuah instansi Pemerintah pasti selalu melakukan yang terbaik dalam upaya 
untuk mengembangkan organisasi, dalam pengembangan tersebut tentu dibutuhkan penanganan sumber daya manusiayang baik, sehingga kinerja sumber daya manusiaakan mencerminkan kinerja institusinya dengan baik pula. Salah satu faktor terpenting peningkatan kinerja adalah tingkat kedisiplinan pegawai dalam mentaati semua aturan atau ketentuan yang berlaku dalam sebuah organisasi, mentaati norma-norma serta budaya organisasi yang telah disepakati bersama merupakan cerminan kedisiplinan pegawai dalam menjalankan tugas mereka, mentaati aturan merupakan sikap prilaku yang dinampakkan melalui realita kehidupan berorganisasi dalam tugas sehari-hari mereka di tempat kerjanya.

\section{Perumusan Masalah}

Berdasarkan latar belakang diatas, penulis merumuskan permasalahan sebagai berikut:

1. Faktor-Faktor apa saja yang mempengaruhi disiplin pegawai terhadap peningkatan kinerja pada Kantor Camat Darussalam Kabupaten Aceh Besar?

2. Faktor mana yang lebih dominan yang mempengaruhi disiplin pegawai terhadap peningkatan kinerja pada Kantor Camat Darussalam Kabupaten Aceh Besar?

\section{Tujuan Penelitian}

Adapun tujuan penelitian ini adalah :

1. Untuk mengetahui faktor-faktor yang mempengaruhi disiplin pegawai terhadap peningkatan kinerja pada Kantor Camat Darussalam Kabupaten Aceh Besar.

2. Untuk mengetahui faktor yang lebih dominan mempengaruhi disiplin pegawai terhadap peningkatan kinerja pada Kantor Camat Darussalam Kabupaten Aceh Besar.

\section{Kegunaan Penelitian}

Adapun manfaat/kegunaan penelitian ini adalah:
1. Dapat memperkaya pengetahuan mengenai kedisiplinan dan kinerja pegawai.

2. Dapat menjadi referensi bagi peneliti selanjutnya yang menyangkut kedisiplinan dan kinerja pegawai.

3. Dapat menyumbangkan saran-saran untuk meningkatkan kedisiplinan pegawai dalam meningkatkan kinerjanya pada Kantor Camat Darussalam Kabupaten Aceh Besar.

\section{Pengertian Disiplin}

Disiplin kerja merupakan suatu kondisi dimana pegawai dalam melakukan tugasnya atau pegawaianya mentaati semua aturan yang telah disepakti bersama, disiplin ini merupakan suatu proses dimana kondisi yang tercipta dan terbentuk melalui proses dari serangkaian perilaku yang menujukkan nilai-nilai ketaatan, kepatuhan, kesetiaan, keteraturan dan ketertiban.

Menurut Hasibuan (2005:193), disiplin yang baik mencerminkan besarnya rasa tanggung jawab seseorang terhadap tugas-tugas yang diberikan kepadanya. Hal ini mendorong gairah kerja, semangat kerja, dan terwujudnya tujuan organisasi, pegawai dan masyarakat.Oleh karena itu, setiap pimpinan selalu berusaha agar para bawahannya mempunyai disiplin yang baik.Untuk memelihara dan meningkatkan kedisiplinan yang baik adalah hal yang sulit, karena banyak faktor yang mempengaruhinya.

Kedisiplinan merupakan fungsi operasional manajemen sumber daya manusiayang terpenting karena semakin baik displin kerja pegawai, semakin baik kinerja yang dapat dicapi. Tanpa disiplin dengan baik sulit bagi organisasi untuk mencapai hasil yang optimal, kedisiplinan merupakan faktor yang utama yang diperlukan sebagai alat peringatan terhadap pegawai yang tidak mau berubah sifat dan perilakunya, sehingga seorang pegawai dikatakan memiliki disiplin yang baik jika pegawai tersebut memiliki rasa tanggungjawab terhadap tugas yang diberikan kepadanya. 
Robin (2006:21) menjelaskan bahwa kontribusi disiplin dalam perilaku organisasi sangat dominan karena disiplin seseorang tidak hanya berhubungan dengan masalah psikologi, tetapi juga berhubungan dengan sosiologi, sosial dan antropologi.

Rivai (2011:825) menerangkan disiplin kerja adalah suatu alat yang dipergunakan para manajer untuk berkomunikasi dengan pegawai agar mereka bersedia untuk mengubah suatu perilaku serta sebagai suatu upaya untuk meningkatkan kesadaran dan kesediaan seorang dalam memenuhi segala peraturan organisasi.

Dari dua pendapat diatas dapat dijelaskan bahwa perilaku disiplin sukar untuk diukur karena perilaku seseorang itu selalu mengalami perubahan. Perubahanperubahan tersebut akan mempengaruhi system social, dimana setiap individu berperan dalam hubungan antara satu dengan yang lainnya. Akibat dari hubungan itu maka terdapat kecenderungan seseorang akan mempengaruhi orang lain, selanjutnya sikap perilaku disiplin juga terbentuk dari budaya dan lingkungan yang berbeda antar organisasi dan antar Negara.

Terkadang kekurangtahuan pegawai tentang peraturan, prosedur, dan akan kebijakan yang ada merupakan penyebab terbanyak tindakan indisipliner. Salah satu upaya untuk mengatasi hal tersebut pihak pimpinan sebaiknya memberikan program orientasi kepada tenaga kerja.Selain memberikan orientasi, pimpinan harus menjelaskan secara rinci peraturanperaturan yang sering dilanggar, berikut rasional dan konsekuensinya.Demikian pula peraturan/prosedur atau kebijakan yang mengalami perubahan atau diperbaharui, sebaiknya diinformasikan kepada staf melalui diskusi aktif.

Disiplin yang baik mencerminkan besarnya rasa tanggung jawab seseorang terhadap tugas-tugas yang diberikan kepadanya.Hal ini mendorong gairah kerja, semangat kerja dan mendukung terwujudnya tujuan organisasi.Disiplin harus ditegakkan dalam suatu organisasi, karena tanpa dukungan disiplin kerja yang baik, maka sulit bagi organisasi atau organisasi untuk mencapai tujuannya.

Menurut Simamora (2006:610) : "Disiplin adalah prosedur yang mengoreksi atau menghukum bawahan karena melanggar peraturan atau prosedur. Disiplin merupakan pengendalian diri pegawai dan pelaksanaan yang teratur dan menujukkan tingkat kesungguhan tim kerja di dalam sebuah organisasi. Tindakan disipliner menuntut suatu hukuman terhadap pegawai yang gagal memenuhi standar yang ditatapakan.Tindakan disipliner yang efektif terpusat pada perilaku pegawai yang salah, bukan pada diri pegawai sebagai pribadi”.

Kedisiplinan pegawai menurut Mangkuprawira (2007:1) adalah sifat seorang pegawai yang secara sadar, mematuhi aturan, dan peraturan organisasi tertentu.Hal itu sangat mempengaruhi kinerja pegawai dan organisasi.Kedisiplinan sepatutnya dipandang sebagai bentuk latihan bagi pegawai dalam melaksanakan aturanaturan organisasi.

Menurut Hasibuan (2013:193) berpendapat bahwa : "Kedisiplinan adalah kesadaran dan kesediaan seseorang menaati semua peraturan organisasi dan normanorma sosial yang berlaku. Kedisiplinan harus ditegakkan dalam suatu oeganisasi organisasi.Tanpa dukungan disiplinan pegawai yang baik, sulit bagi organisasi untuk mewujudkan tujuannya.Jadi, kedisiplinan adalah kunci keberhasilan suatu organisasi dalam mencapai tujuannya."

Sinungan (2010:146) menjelaskan : "Disiplin kerja sebagai suatu sikap mental yang tercermin dalam perbuatan atau tingkah laku perorangan, kelompok atau masyarakat berupa kepatuhan atau ketaatan (obedience) terhadap peraturan-peraturan yang ditetapkan baik oleh pemerintah atau etik, norma, dan kaidah yang berlaku dalam masyarakat untuk tujuan tertentu".

Siagian (2008:305) juga berpendapat bahwa : "Pendisiplinan pegawai adalah suatu bentuk pelatihan yang berusaha memperbaiki dan membentuk pengetahuan, sikap dan perilaku pegawai sehingga para 
pegawai tersebut secara sukarela berusaha bekerja secara kooperatif dengan pegawai yang lainnya".

\section{METODE PENELITIAN Lokasi dan Objek Penelitian}

Penelitian ini dilakukan pada Kantor Camat Darussalam Kabupaten Aceh Besar.Maka yang menjadi objek penelitian adalah faktor-faktor yang mempengaruhi disiplin pegawaiterhadap kinerja padaKantor Camat Darussalam Kabupaten Aceh Besar.

\section{Populasi dan Sampel Populasi}

Populasi adalah wilayah generalisasi yang terdiri atas obyek/subyek yang mempunyai kualitas dan karakteristik tertentu yang ditetapkan oleh peneliti untuk dipelajari dan kemudian ditarik kesimpulannya (Sugiyono, 2009:90).Dalam penelitian ini yang menjadi populasi adalah seluruh pegawai Kantor Camat Darussalam Kabupaten Aceh Besar yang berjumlah 25 orang.

\section{Sampel}

Menurut Arikunto, (2007:149) jika populasi dibawah 100 dapat diambil seluruhnya, akan tetapi jika populasi di atas 100 dapat diambil 10\%-20\% atau 25\%-30\% ataupun lebih. Karena jumlah populasi dalam penelitian ini kurang dari 100, yaitu 25 orang, maka diambil seluruhnya.

\section{Teknik Pengumpulan Data}

Teknik pengumpulan data pada penelitian ini adalah dengan menggunakan data primer yang bersumber pada responden dengan memberikan kuesioner yaitu berisikan pernyataan tentang faktor-faktor yang mempengaruhi disiplin kerja dan tanggapan atas kinerja yang telah diperoleh padaKantor Camat Darussalam Kabupaten Aceh Besar.

\section{Skala Pengukuran}

Data yang dikumpulkan dari penelitian ini terdiri dari 2 jenis data primer dan data sekunder.Hasil penelitian yang diperoleh dari penyebaran kuesioner dalam bentuk kualitatif yang dikomposisikan terlebih dahulu menjadi data kuantitatif. Adapun nilai tersebut yang dikomposisikan dilakukan dengan menggunakan Skala Likert dan satu pilihan dinilai (score) dengan jarak interval 1 . Nilai (score) dari pilihan tersebut antara lain 1,2,3,4 dan 5 masing-masing nilai dari pilihan tersebut dapat dilihat sebagai berikut :

TABEL 3.1

SKALA PENGUKURAN VARIABEL

\begin{tabular}{|c|l|c|}
\hline No & \multicolumn{1}{|c|}{ Indikator } & Skala \\
\hline 1 & Sangat Baik & 5 \\
\hline 2 & Baik & 4 \\
\hline 3 & Kurang Baik & 3 \\
\hline 4 & Tidak Baik & 2 \\
\hline 5 & Sangat Tidak Baik & 1 \\
\hline
\end{tabular}

\section{Uji validitas dan Reliabilitas Alat Ukur}

Pengukuran dalam penelitian ini dilakukan dengan menggunakan kuesinoer digunakan analisis Validitas dan Reliabilitas, maka instrumen yang valid menandakan alat ukur yang digunakan untuk mendapat data itu valid. Dengan demikian instrumen data tersebut dapat mengukur apa yang seharusnya kita ukur, demikian juga suatu instrumen yang reliabel apabila instrumen yang bila digunakan berulang kali untuk mengukur objek yang sama akan menghasilkan data yang sama juga.

Untuk bisa melihat reliabilitas masing-masing instrumen yang digunakan dalam penelitian ini menggunakan koefisiensi Cronvach Alpha, suatu instrumen yang digunakan realibel jika memiliki nilai lebih besar 0,5 Malhotra (1996:305). Maka pengujian vailiditas data dalam penelitian secara statistik yaitu dengan menggunakan uji Pearson product moment coefficient of correlation dari bantuan SPSS versi 21 dengan seluruh pertanyaan dinyatakan valid jika memiliki nilai signifikensi dibawah 0,5 . 


\section{Peralatan Analisis Data}

Dalam menganalisis data guna mengetahui faktor-faktor yang mempengaruhi disiplin yaitu Kehadiran, Ketaatan pada aturan kerja, Ketaatan pada standar kerja, Tingkat kewaspadaan yang tinggi dan Bekerja Etispegawai pada Kantor Camat Darussalam Kabupaten Aceh Besar, diolah dengan menggunakan program SPSS versi 21.

Adapun peralatan analisis data yang digunakan adalah dengan menggunakan metode regresi linear berganda, secara sistimatis bentuk formula regresi sederhana sebagai berikut :

$$
\mathbf{Y}=\mathbf{a}+\beta \mathbf{X}+\mathbf{e}
$$

Dimana :

$$
\begin{aligned}
& \mathrm{Y}=\text { Kinerja } \\
& \mathrm{a}=\text { Konstanta } \\
& \beta=\text { Koefisien regresi } \\
& \mathrm{X}=\text { Disiplin }
\end{aligned}
$$

\section{Operasional Variabel}

Adapun yang menjadi operasional variabel dalam penelitian ini terdiri atas variabel independent disiplin $(\mathrm{X})$ dengan variabel dependent yaitu Kinerja (Y), sebagaimana dijelaskan pada tabel 3.2 berikut:

TABEL

\section{OPERASIONAL VARIABEL}

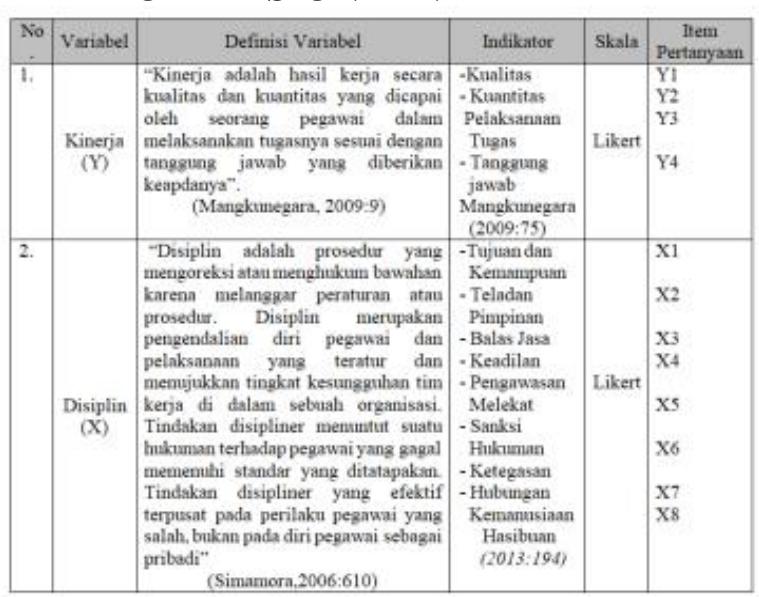

\section{Uji Validitas}

Uji validitas digunakan untuk mengukur sah atau valid tidaknya suatu kuesioner. Suatu kuesioner dikatakan valid jika pertanyaan pada kuesioner mampu untuk mengungkap sesuatu yang akan diukur oleh kuesioner tersebut. (Ghozali, 2011 : 62). Pengujian validitas butir-butir dari kuesioner ini menggunakan metode korelasi product moment, dengan ketentuan jika koefisien korelasi (r) yang diperoleh > dari pada koefisien dari tabel nilai-nilai kritis $\mathrm{r}$, yaitu pada taraf signifikan $5 \%$ atau $1 \%$ instrumen tes yang diujicobakan tersebut dinyatakan valid.

\section{Uji Reliabilitas}

Pengujian keandalan ditunjukkan untuk menguji sejauh mana hasil pengukuran dapat dipercaya.Tinggi rendahnya keandalan digambar melalui koefisien reliabilitas dalam suatu rangka tertentu.Dalam pengujian keandalan digunakan tes konsistensi internal yaitu sistem pengujian terhadap sekelompok tertentu, kemudian dihitung skornya dan diuji konsistensinya terhadap berbagai item yang ada dalam kelompok tersebut. Nilai koefisien alpha bervariasi mulai dari 0 (nol) sampai dengan 1 (satu) dan untuk nilai alphanya $=0,6$ atau kurang memberi indikasi bahwa alat ukur tersebut kurang keandalannya (Sugiyono, 2010 : 137).

\section{Pengujian Hipotesis}

\section{a. Uji t}

Untuk menguji hipotesis dalam penelitian ini penulis menggunakan $\mathrm{Uji} t$ yaitu pada tingkat keyakinan (convident interval 95\%) atau tingkat kesalahannya (alpha) a sebesar 0,05 .

Jika $t_{\text {hitung }}>t_{\text {tabel }}$ tingkat kepercayaan 95\% $(\mathrm{a}=0,05)$, maka terbukti bahwavariabel disiplin secara parsial mempengaruhi kinerja pegawai Kantor Camat Darussalam Kabupaten Aceh Besar. Dengan demikian hipotesis nol (H0) ditolak dan hipotesis alternatif $(\mathrm{Ha})$ diterima.

Jika $\quad t_{\text {hitung }}<t_{\text {tabelp }}$ pada tingkat kepercayaan 95\% $(\mathrm{a}=0,05)$, maka terbukti bahwa variabel disiplin secara parsial tidak mempengaruhi 
kinerja pegawai Kantor Camat Darussalam Kabupaten Aceh Besar. Dengan demikian hipotesis alternative (Ha) ditolak dan hipotesis nol (H0) ditolak.

\section{HASIL PENELITIAN DAN \\ PEMBAHASAN \\ Hasil Penelitian \\ Karakteristik Responden}

Karakteristik responden yang diteliti dalam penelitian ini adalah mencakup jenis kelamin, usia, pendidikan terakhir, pekerjaan, dan pendapatan responden. Hasil pengelolaan data melalui proses komputerisasi dengan program SPSS yang ditunjukkan pada Tabel 4.1 dibawah ini:

Tabel

Karakteristik Responden

\begin{tabular}{|c|c|c|c|}
\hline No. & Uraian & Frekuensi & $\begin{array}{c}\text { Persen } \\
\text { tase }\end{array}$ \\
\hline 1. & $\begin{array}{l}\text { Jenis Kelamin } \\
\text { Pria } \\
\text { Wanita }\end{array}$ & $\begin{array}{l}11 \text { orang } \\
14 \text { orang }\end{array}$ & $\begin{array}{l}44 \% \\
56 \%\end{array}$ \\
\hline 2. & $\begin{array}{l}\text { Usia } \\
<25 \text { tahun } \\
26-30 \text { tahun } \\
31-35 \text { tahun } \\
36-40 \text { tahun } \\
>41 \text { tahun }\end{array}$ & $\begin{array}{c}- \\
4 \text { orang } \\
6 \text { orang } \\
12 \text { orang } \\
3 \text { orang }\end{array}$ & $\begin{array}{c}- \\
16 \% \\
24 \% \\
48 \% \\
12 \%\end{array}$ \\
\hline 3. & $\begin{array}{l}\text { Pendidikan } \\
\text { Terakhir } \\
\text { SMA } \\
\text { Diploma } \\
\text { Sarjana } \\
\text { Pasca Sarjana }\end{array}$ & $\begin{array}{c}9 \text { orang } \\
6 \text { orang } \\
10 \text { orang } \\
-\end{array}$ & $\begin{array}{c}36 \% \\
24 \% \\
40 \% \\
-\end{array}$ \\
\hline 4. & $\begin{array}{l}\text { Masa Kerja } \\
<2 \text { tahun } \\
2-5 \text { tahun } \\
5-10 \text { tahun } \\
>10 \text { tahun }\end{array}$ & $\begin{array}{c}- \\
2 \text { orang } \\
14 \text { orang } \\
9 \text { orang }\end{array}$ & $\begin{array}{c}- \\
8 \% \\
56 \% \\
36 \%\end{array}$ \\
\hline
\end{tabular}

Sumber : Data Primer Diolah (2018)

Berdasarkan hasil penelitian dari tabel 4.1 di atas dapat dijelaskan bahwa karakteristik responden berdasarkan jenis kelamin dapat dijelaskan bahwa responden pria sebanyak $44 \%$, dan responden wanita sebanyak 56\% dari total sampel yang diteliti. Karakteristik berdasarkan tingkat usia dapat dijelaskan bahwa sebanyak
$38,1 \%$ pada usia 26-30 tahun sebanyak $16 \%$, berusia antara 31-35 tahun sebanyak $24 \%$, berusia 36-40 tahun sebanyak $48 \%$ dan diatas 41 tahun sebanyak $12 \%$ dari total responden yang diteliti.

Mengenai tingkat pendidikan terakhir responden, dapat dijelaskan bahwa sebnyak 9,5\% berpendidikan terakhir SMA, sebanyak $65,1 \%$ berpendidikan terakhir Diploma dan sebanyak 25,4\% berpendidikan Sarjana dari total sampel. Karakteristik berdasarkan latar belakang masa kerja menunjukkan bahwa 50,8\% sudah bekerja selama 2-5 tahun, sebanyak 41,3\% sudah bekerja selama 5-10 tahun dan sebanyak $7,9 \%$ sudah bekerja selama $>10$ tahun dari total sampel.

\section{Uji Validitas dan Reliabilitas}

\section{a. Uji Validitas}

Pengujian validitas butir-butir dari kuesioner ini dilakukan secara statistik, yaitu mengunakan metode korelasi product moment, dengan kriteria penentuan jika koefisien korelasi (r) yang diperoleh lebih besar dari pada koefisien dari tabel nilainilai kritis r, yaitu pada taraf sinifikan 5\%.

Nilai $r_{\text {tabel }}$ untuk penelitian ini adalah 0.244.Jika $r_{\text {hitung }}$ lebih besar dari $r_{\text {tabel }}$ maka kuesioner dikatakan valid dan sebaliknya jika $r_{\text {hitung }}$ lebih kecil dari $r_{\text {tabel }}$ maka kuesioner tersebut dikatakan tidak valid sebagai instrumen penelitian. Adapun hasil uji tersebut adalah sebagai berikut :

Tabel

Hasil Uji Validitas

\begin{tabular}{|c|c|c|c|c|}
\hline Variabel & Pertanyaan & $\begin{array}{c}\text { Koefisien } \\
\text { Korelasi }\end{array}$ & Nilai Kritis = 5\% (25) & Ket \\
\hline \multirow{4}{*}{ X } & X1. & 0,783 & 0.396 & Valid \\
\cline { 2 - 5 } & $\mathrm{X} .2$ & 0,833 & 0.396 & Valid \\
\cline { 2 - 5 } & $\mathrm{X} .3$ & 0,674 & 0.396 & Valid \\
\cline { 2 - 5 } & $\mathrm{X} 4$ & 0,714 & 0.396 & Valid \\
\cline { 2 - 5 } & $\mathrm{X} 5$ & 0,855 & 0.396 & Valid \\
\cline { 2 - 5 } & $\mathrm{X} 6$ & 0,734 & 0.396 & Valid \\
\cline { 2 - 5 } & $\mathrm{X} 7$ & 0,805 & 0.396 & Valid \\
\hline \multirow{4}{*}{ Y } & $\mathrm{X} 8$ & 0,790 & 0.396 & Valid \\
\cline { 2 - 5 } & $\mathrm{Y} 1$ & 0,665 & 0.396 & Valid \\
\cline { 2 - 5 } & $\mathrm{Y} 2$ & 0,727 & 0.396 & Valid \\
\cline { 2 - 5 } & $\mathrm{Y} 3$ & 0,765 & 0.396 & Valid \\
\cline { 2 - 5 } & $\mathrm{Y} 4$ & 0,740 & 0.396 & Valid \\
\hline
\end{tabular}

Sumber : Data Primer Diolah (2016)

Hasil tersebut di atas menunjukkan bahwa butir-butir kuesioner dalam penelitian ini adalah valid hal ini 
ditunjukkan dengan nilai $r$ hitung pada masing-masing item lebih besar dari $\mathrm{r}$ tabel (0.396), artinya seluruh butir pertanyaan dapat digunakan sebagai instrumen penelitian.

\section{a. Uji Reliabilitas}

Pengujian kehandalan ditunjukkan untuk menguji sejauh mana hasil pengukuran dapat dipercaya.Tinggi rendahnya keandalan digambarkan melalui koefisien reliabilitas dalam suatu rangka tertentu.Dalam pengujian pengetahuan digunakan tes konsistensi internal yaitu sistem pengujian terhadap sekelompok tertentu, kemudian dihitung skornya dan diuji konsistensinya terhadap berbagai item yang ada dalam kelompok tersebut. Nilai koefisien alpha bervariasi mulai dari 0 (nol) sampai dengan 1 (satu) dan untuk nilai alphanya $=0,60$ atau kurang memberi indikasi bahwa alat ukur tersebut kurang kehandalannya.

Tabel

Reliabilitas Variabel Penelitian Alpha

\begin{tabular}{|c|l|c|c|c|}
\hline No & \multicolumn{1}{|c|}{ Variabel } & Item Variabel & Nilai Alpha & Kehandalan \\
\hline 1 & Disiplin (X) & 8 & 0,725 & Handal \\
\hline 2 & Kinerja pegawai (Y) & 4 & 0,691 & Handal \\
\hline
\end{tabular}

Sumber : Data Primer Diolah (2016)

Berdasarkan tabel 4.3 diatas dapat diketahui bahwa alpha untuk masing-masing variabel yaitu variabel Disiplin (X) diperoleh nilai alpha sebesar 0,725 dan variabel Kinerja Pegawai (Y) diperoleh nilai alpha sebesar 0,691. Dengan demikian pengukuran reliabilitas terhadap variabel penelitian menunjukkan bahwa pengukuran kehandalan memenuhi syarat reliabilitas atau dengan kata lain bahwa kuesioner ini reliabel sebagai instrumen penelitian.

\section{Pembahasan}

Faktor-Faktor yang Mempengaruhi Disiplin Pegawai TerhadapPeningkatan Kinerja pada Kantor Camat Darussalam Kabupaten Aceh Besar

Kehadiran, faktor ketaatan pada aturan kerja, faktor ketaatan pada standar kerja, faktor tingkat kewaspadaan yang tinggi, dan faktor bekerja etis, dengan mengambil sampel adalah seluruh pegawai yang 25 orang yang akan menjadi respoden dalam penelitian ini.

Dari penelitian yang dilakukan dengan metode input data memakai kuesioner kepada responden dan data tersebut dianalisa dengan memakai skala likert, pengolahan data dipergunakan program SPSS versi 21, maka dari hasil output hasilnya dimana pengujian regresi dapat dilihat pada Tabel 4.10 berikut:

Tabel

Pengaruh Masing-masing Variabel Independen Terhadap Variabel Dependen

\begin{tabular}{|c|c|c|c|c|c|c|}
\hline Nama Variabel & B & $\begin{array}{c}\text { Standar } \\
\text { Error }\end{array}$ & Beta & $t_{\text {hitung }}$ & $t_{\text {tabel }}$ & Sign \\
\hline Konstanta & 2,047 & 2,551 & &, 802 & 2.064 &. .431 \\
\hline Disiplin & .952 & .080 & .933 & 11,899 & 2.064 & .000 \\
\hline \multicolumn{7}{|c|}{ Koefisien Korelasi $(\mathrm{R}) \quad=0,933$} \\
\hline \multicolumn{2}{|l|}{ Koefisien Determinasi $\left(\mathrm{R}^{2}\right)$} & 0,871 & & & & \\
\hline \multicolumn{2}{|l|}{ Adjusted R Squares } & 0,865 & & & & \\
\hline
\end{tabular}

Sumber : Data Primer Penelitian Diolah (2019)

Dari output SPSS di atas dengan dipergunakan model regresi berganda, dapat difungsikan dalam bentuk persamaan sebagai berikut :

$$
\mathrm{Y}=2.047+0.952 \mathrm{X}
$$

Dari persamaan regresi linear sederhana di atas dapat dijelaskan sebagai berikut :

a. Nilai konstanta sebesar 2.047 artinya jika Disiplin (X), dianggap konstan, maka Kinerja pegawai pada Kantor Camat Darussalam Kabupaten Aceh Besar adalah sebesar 2.047.

b. Nilai koefisien regresi Pengetahuan sebesar 0.952 dapat diartikan bahwa setiap 1\% kenaikan Disiplin (X) maka akan meningkatkan Kinerja Pegawai pada Kantor Camat Darussalam Kabupaten Aceh Besar sebesar 0,952\%. Ini berarti terjadi Kinerja Pegawai pada Kantor Camat Darussalam Kabupaten Aceh Besar.

Hubungan antara variabel dependen dan independen yaitu variabel Disiplin (X), 
terhadap Kinerja Pegawai pada Kantor Camat Darussalam Kabupaten Aceh Besar dengan indeks korelasi sebesar $\mathbf{0 , 9 3 3 ~ \% ~ i n i ~}$ berarti hubungan tersebut sangat kuat.

Kemudian indeks determinasi variabel Disiplin (X), sebesar $0,871 \%$ ini berarti variable Disiplin berpengaruh secara signifikan terhadap Kinerja Pegawai padaKantor Camat Darussalam Kabupaten Aceh Besar, dan sebesar $12,9 \%$ yang dipengaruhi oleh variabel lain yang tidak diteliti dalam penelitian ini.

\section{Hasil Pengujian Hipotesis Uji T}

Pengujian ini untuk melihat sejauh mana pengaruh secara terpisah dari masingmasing variabel Pengetahuan $\left(\mathrm{X}_{1}\right)$, Keterampilan $\left(\mathrm{X}_{2}\right)$, Perilaku $\left(\mathrm{X}_{3}\right)$, dan Pengalaman Kerja $\left(\mathrm{X}_{4}\right)$ terhadap variabel terikat (Y) berdasarkan hasil regresi yang ada, Uji $\mathrm{T}$ dilakukan dengan membandingkan nilai t hitung dengan $\mathrm{t}$ tabel dengan tingkat kesalahan 5\%. Uji $t$ dilakukan untuk melihat signifikan dari pengaruh variabel independen secara individu terhadap variabel dependen (Secara parsial). Pembuktian hipotesis secara parsial dapat dijelaskan seperti tabel 4.5 di bawah ini, maka dapat disajikan sebagai berikut :

Tabel

Hasil Analisis Uji T

\begin{tabular}{|l|r|r|r|r|r|r|}
\hline \multicolumn{1}{|c|}{ Nama Variabel } & \multicolumn{1}{c|}{ B } & $\begin{array}{c}\text { Standar } \\
\text { Error }\end{array}$ & Beta & t thing & $t_{\text {tabel }}$ & Sign \\
\hline Konstanta & 2,047 & 2,551 & &, 802 & 2.064 &. .431 \\
\hline Disiplin & .952 & .080 & .933 & 11,899 & 2.064 & .000 \\
\hline
\end{tabular}

Sumber : Data Primer Penelitian Diolah (2019)

Berdasarkan Tabel 4.12 di atas dapat dilihat bahwa Variabel Disiplin (X) diperoleh $t_{\text {hitung }} 11.899>t_{\text {tabel }} 2,064$ dan nilai signifikan $0.000<0.05$, sehingga Hipotesis Nol (Ho) diterima dan Hipotesis Alternatif (Ha) ditolak. Dari hasil uji $\mathrm{t}$ ini dapat disimpulkan bahwa variabel Disiplin (X) berpengaruh secara signifikan terhadap Kinerja Pegawai pada Kantor Camat Darussalam Kabupaten Aceh Besar.

\section{KESIMPULAN DAN SARAN \\ Kesimpulan}

Kesimpulan dari hasil penelitian tentang "Faktor-faktor yang mempengaruhi Disiplin Terhadap Kinerja Pegawai Pada Kantor Camat Darussalam Kabupaten Aceh Besar" adalah sebagai berikut :

1. Berdasarkan hasil analisis di atas dapat disimpulkan bahwa variabel Disiplin (X) mempunyai pengaruh yang siqnifikan terhadap Kinerja pegawai pada Kantor Camat Darussalam Kabupaten Aceh Besar.

2. Hubungan antara variabel dependen dan independen yaitu Disiplin (X) terhadap Kinerja (Y) pegawai pada Kantor Camat Darussalam Kabupaten Aceh Besar dengan indeks korelasi sebesar 0,933\% ini berarti hubungan tersebut sangat kuat.

3. Kemudian indeks determinasi sebesar $0,871 \%$, ini berarti variabel Disiplin berpengaruh secara signifikan terhadap Kinerja Pegawai pada Kantor Camat Darussalam Kabupaten Aceh Besar, dan hanya sebesar 12,9\% yang dipengaruhi oleh variabel lain yang tidak diteliti dalam penelitian ini.

4. Variabel Disiplin (X) diperoleh $t_{\text {hitung }}$ $11,899>t_{\text {tabel }}, 2,064$ dan nilai signifikan $0.000<0.05$, sehingga Hipotesis Nol (Ho) diterima dan Hipotesis Alternatif (Ha) ditolak. Dari hasil uji $t$ ini dapat disimpulkan bahwa variabel Disiplin (X) berpengaruh secara signifikan terhadap Kinerja Pegawai pada Kantor Camat Darussalam Kabupaten Aceh Besar.

\section{Saran-saran}

Untuk kegunaan penelitian dan pebaikan disiplin dilingkunganKantor Camat Darussalam maka saya berikan beberapa saran. Adapun saran yang dapat saya berikan adalah sebagai berikut :

1. Untuk meningkatkan Kinerja pegawai pada Kantor Camat Darussalam Kabupaten Aceh Besar, sebaiknya pimpinan harus lebih memperhatikan dan fokus terhadap kedisiplinan pegawainya.

2. Untuk menciptakan Kinerja pegawai yang sesuai harapan, sebaiknya standar 
kerja dan peraturan yang menyangkut kedisiplinan pegawai harus diinformasikan kepada seluruh pegawai pada Kantor Camat Darussalam Kabupaten Aceh Besar.

\section{DAFTAR PUSTAKA}

Dessler, Garry (2008), Manajemen Sumber Daya Manusia, Buku 1 \& 2 Jakarta; Indeks.

Handoko (2006), Manajemen Sumber Daya Manusia, STIE YPKN, Jakarta.

Hasibuan. Melayu S.P (2007), Manajemen Sumber Daya Manusia, PT. Bumi Aksara, Jakarta.

Muhammad Idrus, (2009), Metode Penelitian Ilmu Sosial, Edisi Kedua Erlangga Jakarta.

Mangkunegara (2009), Manajemen Sumber Daya Organisasi, Bandung. PT. Remaja Rosdakarya Offset.

Mulyadi dan Setiawan (2011), Balance Scorecard, Alat Manajemen Kontemporer Untuk Pelipatganda Kinerja Keuangan Organisasi, Edisi II, Jakarta, Selemba Empat.

Malaya Hasibuan(2005), Manajemen Sumber Daya Manusia, Penerbit BPFE Yogyakarta.

Nitisemito, Alex S, (2008) Manajemen Personalia (Manajemen Sumber Daya Manusia), Edisi Ketiga, Jakarta : PT. Ghalia Indonesia.

Nasution, S (2006), Metode Research, Bumi Aksara Jakarta,

Simamora (2006), Manajemen Sumber

Daya Manusia, Penerbit Fakultas
Ekonomi Universitas Indonesia, Jakarta.

Sastrohadiwiyo, B. Siswanto (2013), Disiplin Kiat Menuju Sukses, Edisi Kedua Cetakan Silemba Jakarta.

Sinuga Muchdarsyah (2010), Manajemen Sumber Daya Manusia, Salemba Empat Jakarta.

Sony Yuwono, Edi Sukono dan Ichsan (2006), Manajemen Sumber Daya Manusia Strategik, Jakarta, Ghalia Indonesia.

Siagian (2008), Teori Motivasi dan Aplikasinya, Jakarta Rineka Cipta

Sudarmayanti (2008), Manajemen Ketenagakerjaan, Pustaka ilmu, Jakarta.

Sulistiyani dan Rosidah (2005), Manajemen Personalis dan Sumber Daya Manusia, Yogyakarta BPFE, UGM.

Robbins (2006), Prilaku Organisasi, PT. Indeks Jakarta.

Veithzal Rizal (2011), Manajemen Sumber daya manusiauntuk Organisasi dari Teori dan Praktek, PT. Rajagrafindo Persada Jakarta. 